\title{
PENGARUH TAMPILAN WEB DAN HARGA TERHADAP MINAT BELI DENGAN KEPERCAYAAN SEBAGAI INTERVENING VARIABLE PADA E-COMMERCE SHOPEE
}

\author{
Edwin Japarianto ${ }^{1 *}$, Stephanie Adelia ${ }^{2}$ \\ ${ }^{1,2}$ Fakultas Ekonomi dan Bisnis, Universitas Kristen Petra \\ J1. Siwalankerto 121-131, Surabaya 50236 \\ Email: 1edwinj@petra.ac.id; ${ }^{2}$ stefanieadelia97@gmail.com \\ *Penulis korespondensi
}

\begin{abstract}
Abstrak:E-commerce dipengaruhi oleh berbagai macam faktor, misalnya tampilan web dan harga, serta kepercayaan yang ikut andil dalam mempengaruhi pertumbuhan minat beli online.Dari penelitian ini penulis menemukan bahwa hubungan antara tampilan web dan harga pada minat beli dengan kepercayaan sebagai intervening variable-nya di e-commerce Shopee menunjukkan bahwa kepercayaan merupakan variabel intervening, membuat variabel independen lebih kuat apabila secara langsung berhubungan ke variabel dependen. Responden dalam penelitian ini adalah pengguna aplikasi Shopee yang menggunakan aplikasi Shopee dalam tiga bulan terakhir dan membuka aplikasi Shopee minimal lima kali.
\end{abstract}

Kata kunci: E-commerce; tampilan web; harga; kepercayaan; minat beli.

\begin{abstract}
E-commerce influenced by a variety of factors, such as the web display and the price, as well as the trust that contributes to influencing the growth of online buying interest. From this studies the author finds that the relationship between web appearance and prices on buying interest with trust as an intervening variable in e-commerce Shopee shows that trust is an intervening variable, makes the independent variable it is stronger if it is directly related to the dependent variable.Respondents in this study were Shopee application users who used the Shopee application in the last three months and opened Shopee applications at least five times.
\end{abstract}

Keywords: E-commerce; web display; price; trust; purchase intention.

\section{PENDAHULUAN}

Minat beli konsumen dalam aktivitas perdagangan menjadi semakin berkembang karena adanya kemajuan teknologi. Teknologi yang semakin berkembang menyebabkan perdagangan semakin tidak terbatas waktu dan tempat. Jika dahulu perdagangan hanya dapat dilakukan melalui pertemuan tatap muka, kini melalui adanya jaringan internet perdagangan dapat dilakukan tanpa perlu bertatap muka seperti puluhan tahun silam.

Minat membeli yang dilakukan dengan media online adalah keinginan seseorang untuk membeli suatu produk yang ditawarkan oleh produsen kepada konsumen melalui media online. (Adidarma, 2016).

Menjamurnya platform e-commerce di Indonesia membuat masing-masing platform mengerahkan seluruh strategi, kemampuan, dan keunikannya untuk meningkatkan traffic kunjungan dan sales dari mitra-mitra pelapak yang bekerja sama dengan mereka, baik dari segitampilan website serta harga, dikarenakan pembeli hanya dapat berhubungan dengan perusahaan melalui website dan harga tentunya faktor yang sangat dipertimbangkan oleh konsumen sebelum berbelanja online.

Tampilan web yang menarik akan membuat minat beli konsumen akan meningkat. Unsur-unsur yang penting dalam tampilan web misalnya kemudahan akses, kemudahan transaksi, informasi web, perlu diperhatikan oleh e-commerce.

Harga juga menentukan apakah konsumen akan jadi memiliki minat beli di suatu e-commerce. Unsurunsur penting dalam harga adalah potongan harga, keterjangkauan harga, kesesuaian harga dengan kualitas perlu diperhatikan oleh e-commerce.

Selain itu ada faktor penting lain dalam berbelanja online yang berasal dari intern setiap individu, yakni kepercayaan. Kepercayaan merupakan hal penting dan krusial dalam kegiatan ekonomi, terutama untuk berjaga-jaga terhadap perilaku oportunistik yang tidak diinginkan. Apalagi dalam sektor online shoping, menurut David Gefen, Elena Karahanna, dan Detmar W Straub dalam jurnalnya yang bertajuk Trust and Tam in Online Shopping (2003), isu kepercayaan ini lebih krusial daripada saat belanja dilakukan face-to-face, karena jika berbelanja secara online pembeli memiliki lebih sedikit ruang dan waktu untuk menilai produk yang akan pembeli belanjakan. Biasanya, calon pembeli akan melihat terlebih dulu testimonial dari produk tersebut di online shop yang akan ia beli.

Shopee merupakan perusahaan e-commerce yang berada di bawah naungan SEA Group atau dulunya dikenal dengan nama Garena, perusahaan 
internet di Asia Tenggara. Shopee memiliki pendownload nomor satu terbanyak di Indonesia, namun masih berada di peringkat empat jumlah visitor perbulannya.

Berdasarkan latar belakang permasalahan di atas, maka rumusan masalah penelitian ini adalah" Apakah tampilan web dan harga mempengaruhi minat beli dan kepercayaan merupakan variabel interveningnya di e-commerce Shopee?"

\section{TINJAUAN PUSTAKA}

\section{Web Design}

Menurut (Rosandiena \& Indrojarwo, 2018) desain web adalah jenis desain grafis yang ditujukan untuk pengembangan dan styling obyek lingkungan informasi internet untuk menyediakan dengan fitur konsumen high-end dan kualitas estetika. Definisi ini memisahkan desain web dari pemrograman web, menekankan fitur fungsional dari sebuah situs web. Tujuan desain web adalah untuk membuat situs web atau dokumen elektronik dan aplikasi yang berada pada web server dan menampilkan konten dan fitur antarmuka interaktif serta menarik kepada pengguna akhir dalam bentuk halaman Web.

Menurut (Wicaksono, Susanto, \& Winarno, 2012) penyusunan tata letak tampilan secara visual yang sederhana tetapi tetap menarik tanpa mengurangi informasi yang dibutuhkan oleh pengguna dan menyediakan informasi yang selalu di-update adalah hal yang penting. Tampilan desain website hendaknya dilakukan pergantian secara berkala untuk menghindari tampilan website yang membosankan, namun tetap memegang prinsip tampilan yang interaktif (atraktif), menarik, dan tidak membingungkan pengguna, sehingga mudah untuk dipelajari.

\section{Indikator Web Design (diadaptasi dari buku Marketing Scales)}

a. Kelengkapan Informasi

b. Efisiensi Website

c. Kemudahan transaksi

d. Tingkat personalisasi

e. Pilihan/tombol yang bagus

\section{Price Strategy}

Harga adalah jumlah semua nilai yang diberikan oleh pelanggan untuk mendapatkan keuntungan dari memiliki atau menggunakan suatu produk atau jasa (Kotler \& Armstrong, 2008).

\section{Indikator Harga (Kotler \& Armstrong, 2008)}

a. Keterjangkauan Harga b. Kesesuaian Harga dengan Kualitas

c. Daya Saing Harga

d. Kesesuaian Harga dengan Manfaat

\section{Minat Beli}

Menurut (Kotler, 2005) minat (Interest) digambarkan sebagai situasi dimana konsumen belum melakukan suatu tindakan, yang dapat dijadikan dasar untuk memprediksi perilaku atau tindakan tersebut. Minat merupakan perilaku yang muncul sebagai respon terhadap suatu objek yang menunjukkan keinginan pelanggan untuk melakukan pembelian. (Kurnia, 2010) berpendapat minat beli merupakan timbulnya suatu keinginan dalam diri konsumen terhadap suatu produk sebagai dampak dari proses pengamatan dan pembelajaran konsumen terhadap produk tersebut.

Minat beli adalah kecenderungan untuk merasa tertarik atau terdorong untuk melakukan kegiatan mendapatkan dan memiliki barang dan jasa. Minat beli merupakan pernyataan mental konsumen yang merefleksikan rencana pembelian suatu produk dengan merek tertentu (Penitasari, 2017). Sedangkan menurut (Kinnear \& Taylor, 1996) minat beli adalah tahap kecenderungan konsumen untuk bertindak sebelum keputusan membeli benar-benar dilaksanakan. Sejalan dengan (Howard, 1994) yang berpendapat minat beli merupakan sesuatu yang berhubungan dengan rencana konsumen untuk membeli produk tertentu serta berapa banyak unit produk yang dibutuhkan pada periode tertentu.

Dari beberapa pendapat ahli di atas, dapat disimpulkan bahwa minat beli merupakan pernyataan dalam diri konsumen yang menunjukkan kecenderungan atau ketertarikan konsumen untuk membeli sebuah produk dalam jumlah tertentu dan periode waktu tertentu yang dapat digunakan oleh pihak pemasar untuk menjadi prediksi keinginan pelanggan.

Minat beli timbul setelah adanya proses evaluasi alternatif. Di dalam proses evaluasi, seseorang akan membuat suatu rangkaian pilihan mengenai produk yang hendak dibeli atas dasar merek maupun minat.(Kotler, Bowen, \& Maken, 1999)

\section{Indikator Minat Beli}

Menurut (Ferdinand, 2002), minat beli dapat diidentifikasi melalui empat indikator berikut ini:

a. Minat transaksional, yaitu kecenderungan seseorang untuk membeli produk.

b. Minat referensial, yaitu kecenderungan seseorang untuk mereferensikan produk kepada orang lain.

c. Minat preferensial, yaitu minat yang menggambarkan perilaku seseorang yang memiliki 
prefrensi utama pada produk tersebut. Preferensi ini hanya dapat diganti jika terjadi sesuatu dengan produk preferensinya.

d. Minat eksploratif, minat ini menggambarkan perilaku seseorang yang selalu mencari informasi mengenai produk yang diminatinya dan mencari informasi untuk mendukung sifat-sifat positif dari produk tersebut.

\section{Kepercayaan}

Kepercayaan konsumen didefinisikan sebagai harapan konsumen bahwa penyedia jasa dapat dipercaya atau diandalkan dalam memenuhi janjinya. (Siagian \& Cahyono, 2014). Kepercayaan konsumen menyangkut kepercayaan bahwa suatu produk memiliki berbagai atribut dan manfaat dari berbagai atribut tersebut (Sulistyari, 2012). Kepercayaan merupakan keyakinan satu pihak mengenai maksud dan perilaku pihak yang lainnya. Pendapat lain mengemukakan kepercayaan sebagai derajat di mana seseorang yang percaya menaruh sikap positif terhadap keinginan baik dan keandalan orang lain yang dipercayanya di dalam situasi yang berubah ubah (Das \& Ten, 1998). (Schurr \& Ozanne, 1985) mendefinisikan kepercayaan sebagai keyakinan bahwa janji atau janji pihak tersebut dapat diandalkan dan bahwa suatu pihak akan memenuhi kewajibannya dalam suatu hubungan pertukaran. Dengan demikian kepercayaan konsumen didefinisikan sebagai harapan konsumen bahwa penyedia barang dan jasa dapat dipercaya atau diandalkan dalam memenuhi janjinya. (Bilondatu, 2013)

Kepercayaan konsumen telah diakui dalam literatur pemasaran sebagai faktor penting untuk perdagangan bisnis yang sukses, serta pengembangan dan manajemen untuk hubungan pelanggan jangka panjang. (Hahn \& Kim, 2009)

\section{Dimensi Kepercayaan}

Menurut (Mayer, Davis, \& Schoorman, 1995) ada tiga dimensi kepercayaan:

a. Kemampuan (Ability)

Kemampuan mengacu pada kompetensi suatu organisasi.

b. Kebaikan hati (Benevolence)

Kebaikan hati merupakan kemauan penjual dalam memberikan kepuasan yang saling menguntungkan antara dirinya dengan konsumen.

c. Integritas (Integrity)

Integritas berkaitan dengan bagaimana perilaku atau kebiasaan penjual dalam menjalankan bisnisnya. Informasi yang diberikan kepada konsumen apakah benar sesuai dengan fakta atau tidak.

\section{Hubungan Antar Konsep}

\section{Hubungan antara Harga dengan Minat Beli}

Harga sangat mempengaruhi minat beli dikarenakan kemampuan konsumen untuk membeli sebuah produk ditentukan dengan uang yang mereka miliki dan membandingkan dengan fasilitas yang mereka dapatkan ketika membeli suatu produk (Prabowo, 2016).

\section{Hubungan Tampilan Web dengan Minat Beli}

Faktor tampilan web ini berkaitan dengan bagaimana operasional berbelanja secara online. Meskipun belanja online memiliki banyak manfaat, namun kerumitan dalam berinteraksi dengan medianya dalam hal ini adalah situs jual beli online, bisa menjadi sesuatu yang membingungkan untuk pengguna. Tampilan web berhubungan dengan mudah atau tidaknya situs digunakan dan dipahami oleh calon pembeli. Biasanya calon pembeli akan mengalami kesulitan pada saat pertama kali melakukan belanja online, serta cenderung mengurungkan niatnya karena ketidaktahuan dalam bertransaksi online. Dalam kasus belanja online, situs web adalah satu-satunya cara perusahaan berkomunikasi dengan pelanggannya. Oleh karena itu, tampilan dan strukturnya dapat mendorong atau mengecilkan minat pembelian konsumen (Chen \& Dhillon, 2003).

\section{Hubungan Harga dengan Kepercayaan}

Menurut (Pavlou \& Dimoka, 2006) pemisahan fisik yang ada di antara pembeli dan penjual dalam berbelanja online menimbulkan ketidakpastian bagi pembeli karena mereka kebanyakan bertransaksi dengan penjual baru dan tidak dikenal tanpa nama merek. Untuk menjelaskan ketidakpastian ini, ecommerce telah mengembangkan mekanisme umpan balik, yang merupakan sistem TI yang memungkinkan pengumpulan dan penyebaran informasi tentang transaksi penjual di masa lalu. Mekanisme umpan balik juga telah ditunjukkan untuk memberikan harga terpercaya untuk penjual yang bereputasi baik. Dalam transaksi online, konsumen mau membayar harga lebih tinggi bagi vendor yang lebih bisa dipercaya (Cahyaningdyah, 2013).

\section{Hubungan Tampilan Web dengan Kepercayaan}

Pada konteks internet, fungsi penjual digantikan oleh website (Lohse \& Spiller, 1998). Hal ini menyebabkan tampilan dan kualitas website dapat menjadi faktor yang dapat membangun kepercayaan konsumen online. Dalam penelitian menjelaskan bahwa 
tampilan sebuah web dapat meningkatkan kepercayaan konsumen yang melakukan transaksi secara online, karena konsumen yang bertransaksi secara online mengandalkan informasi yang di dapat dari website yang menjual produk dan jasa tersebut (Zhang, Zhu, \& Huang, 2009).Penjual yang memiliki kualitas website yang bagus, meskipun mereka tidak memiliki reputasi yang bagus, tetap lebih dipercaya daripada penjual yang memiliki reputasi yang bagus, tetapi kualitas website jelek (Gregg \& Walczak, 2010).

\section{Hubungan Kepercayaan dengan Minat Beli}

Konsep kepercayaan yang sudah dibahas penulis di atas menunjukkan bahwa kepercayaan memegang peran penting, karena konsumen yang sudah percaya akan berminat untuk membeli kepada perusahaan (Endi \& Lilis, 2014). Faktor kepercayaan memiliki pengaruh langsung pada minat beli konsumen. Dalam konteks berbelanja online, hubungan antara keduanya bersifat positif berlaku terhadap pembeli potensial (konsumen yang memiliki minat beli online) (Ricky \& Adrian, 2012). Semakin tinggi tingkat kepercayaan konsumen, semakin tinggi minat pembelian konsumen (Jarvenpaa, Tractinsky, \& Vitale, 2000). Hanya pelanggan yang memiliki kepercayaan yang akan berminat untuk membeli secara online (Yusnidar, Samsir, \& Restuti, 2014). Terbangunnya rasa percaya konsumen dan adanya rasa aman terhadap penjual maupun situs jual beli online dapat meningkatkan minat beli konsumen di situs tersebut (Koufaris \& Hampton-Sosa, 2004; Njite \& Parsa, 2005).

\section{Kerangka Konseptual}

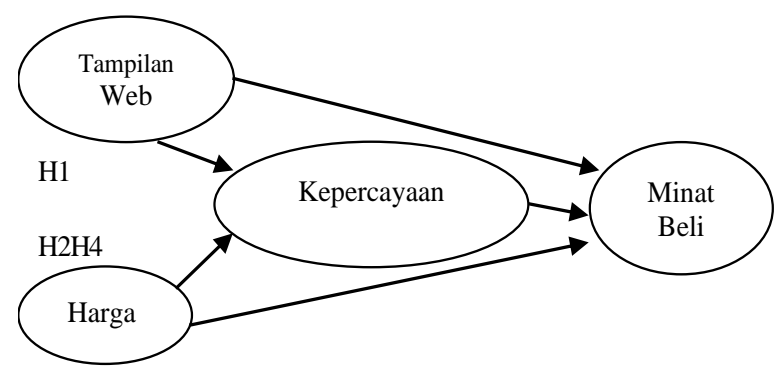

Gambar 1. Kerangka Konseptual

\section{Hipotesis}

Berdasarkan pengamatan di lapangan dan studi literatur maka dirumuskan hipotesis sebagai berikut:

H1: Terdapat pengaruh positif harga terhadap minat beli di Shopee.

$\mathrm{H} 2$ : Terdapat pengaruh positif tampilan web terhadap minat beli di Shopee.
H3: Terdapat pengaruh positif harga terhadap kepercayaan kepada Shopee.

H4: Terdapat pengaruh positif tampilan web terhadap kepercayaan kepada Shopee.

H5: Terdapat pengaruh positif kepercayaan terhadap minat beli di Shopee.

\section{METODOLOGI PENELITIAN}

\section{Populasi dan Sampel}

Menurut (Churchill, 2005; Parasuraman, 1991) populasi merupakan gabungan elemen yang memiliki berbagai karakteristik yang serupa, dan mencakup semesta untuk kepentingan masalah riset pemasaran. Populasi dalam penelitian ini adalah pengguna aplikasi dari PT. Shopee di Surabaya.

Sampel merupakan unsur-unsur dari jumlah dan karakteristik yang dimiliki oleh populasi dimana peneliti ingin melakukan kajian pemasaran (Wahdi, 2011).

Teknik pengambilan sampel pada penelitian ini menggunakan teknik purposive sampling dimana peneliti melakukan penilaian untuk memilih anggota populasi yang merupakan pengguna aplikasi Shopee (pernah membuka website/mendownload dan membuka aplikasi Shopee) minimal 5x dalam 3 bulan terakhir (Juli 2018 - September 2018) namun belum pernah melakukan transaksi di Shopee sebanyak minimal 100 orang.

\section{Definisi Operasional Variabel}

Definisi operasional variabel yang akan digunakan terdiri dari 3 variabel:

1. Variabel Independen,

A. Web Design $\left(\mathrm{X}_{1}\right)$

$\mathrm{X}_{1} .1$ Informasi yang diberikan oleh website lengkap.

$\mathrm{X}_{1.2}$ Website mudah diakses.

$\mathrm{X}_{1} .3$ Website memudahkan konsumen dalam bertransaksi.

$\mathrm{X}_{1} .4$ Website memiliki layout yang menarik.

B. Harga $\left(\mathrm{X}_{2}\right)$

$\mathrm{X}_{2} .1$ Harga produk terjangkau.

$\mathrm{X}_{2} .2$ Kualitas produk sesuai dengan harganya.

$\mathrm{X}_{2} 3$ Produk memiliki harga bersaing.

$\mathrm{X}_{2} .4$ Konsumen memperhatikan potongan harga.

2. Variabel Dependen

A. Minat Beli $\left(\mathrm{Y}_{1}\right)$

a. Minat Transaksional.

$\mathrm{Y}_{1.1}$ Konsumen berminat membeli produk melalui aplikasi Shopee.

b. Minat Referensial.

$\mathrm{Y}_{1.2} 2$ Konsumen berminat merekomendasikan kerabat untuk menggunakan Shopee. 
c. Minat Preferensial.

$Y_{1} 3$ Konsumen akan menjadikan Shopee sebagai pilihan pertama dalam berbelanja online.

d. Minat Eksploratif.

$\mathrm{Y}_{1.4}$ Konsumen akan selalu mencari informasi terbarutentang Shopee.

3. Variabel Intervening

A. $\operatorname{Kepercayaan}\left(\mathrm{Z}_{1}\right)$

a. Ability.

$\mathrm{Z}_{1} 1$ Konsumen percaya bahwa Shopee mampu menjaga keamanan informasi pribadi seperti alamat rumah dan nomor telepon.

$\mathrm{Z}_{1} 2$ Konsumen percaya bahwa Shopee mampu memverifikasi pembayaran dan memproses transaksi setelah pembayaran.

$\mathrm{Z}_{1.3}$ Konsumen percaya Shopee mampu menampilkan penjual yang memiliki reputasi baik dengan suatu penanda (Star Seller).

b. Benevolence.

$\mathrm{Z}_{1.4}$ Shopee memberi notifikasi khusus yang menguntungkankonsumen.

$\mathrm{Z}_{1.5}$ Shopee banyak memberikan reward (pemberian koin Shopee ketika check in, ada event "Goyang Shopee" untuk mendapat koin) kepada konsumennya.

c. Integrity.

$\mathrm{Z}_{1} 6$ Shopee memberi informasi promosi secara transparan kepada konsumen.

$\mathrm{Z}_{1.7}$ Shopee meng "update" informasi program secara transparan kepada konsumen.
$\mathrm{Z}_{1.8}$ Shopee memberi informasi harga produk secara transparan kepada konsumen.

\section{Teknik Analisis Data}

Pemilihan teknik analisa statistika adalah bagian penting untuk megnuji hipotesis salah satu alat analisis yang banyak digunakan adalah SEM (structural equation marketing). Penelitian ini menggunakan pendekatan WarpPLS yang merupakan pengembangan dari analisis PLS (partial least square), model ini dikembangkan sebagai alternative untuk situasi dimana dasar teori pada perancangan model lemah atau indikator yang tersedia tidak memenuhi model pengukuran reflesif.

\section{HASIL PENELITIAN DAN PEMBAHASAN}

\section{Path Analysis}

Pada analisa path coefficient ini telah terbukti bahwa kepercayaan merupakan variable intervening dimana tidak memperkuat hubungan antara tampilan web dengan minat belidengan kepercayaan sebesar 0.131 yang merupakan hasil perkalian antara 0.627 dan 0.210, di mana hubungan tampilan web secara langsung ke minat beli lebih besar, yaitu 0.343 . Kepercayaan juga merupakan variable intervening yang tidak memperkuat hubungan antara harga dengan minat belidengan kepercayaan sebesar 0.056 yang merupakan hasil perkalian antara 0.271 dan 0.210 , di mana hubungan harga secara langsung ke minat beli lebih besar, yaitu 0.386 .

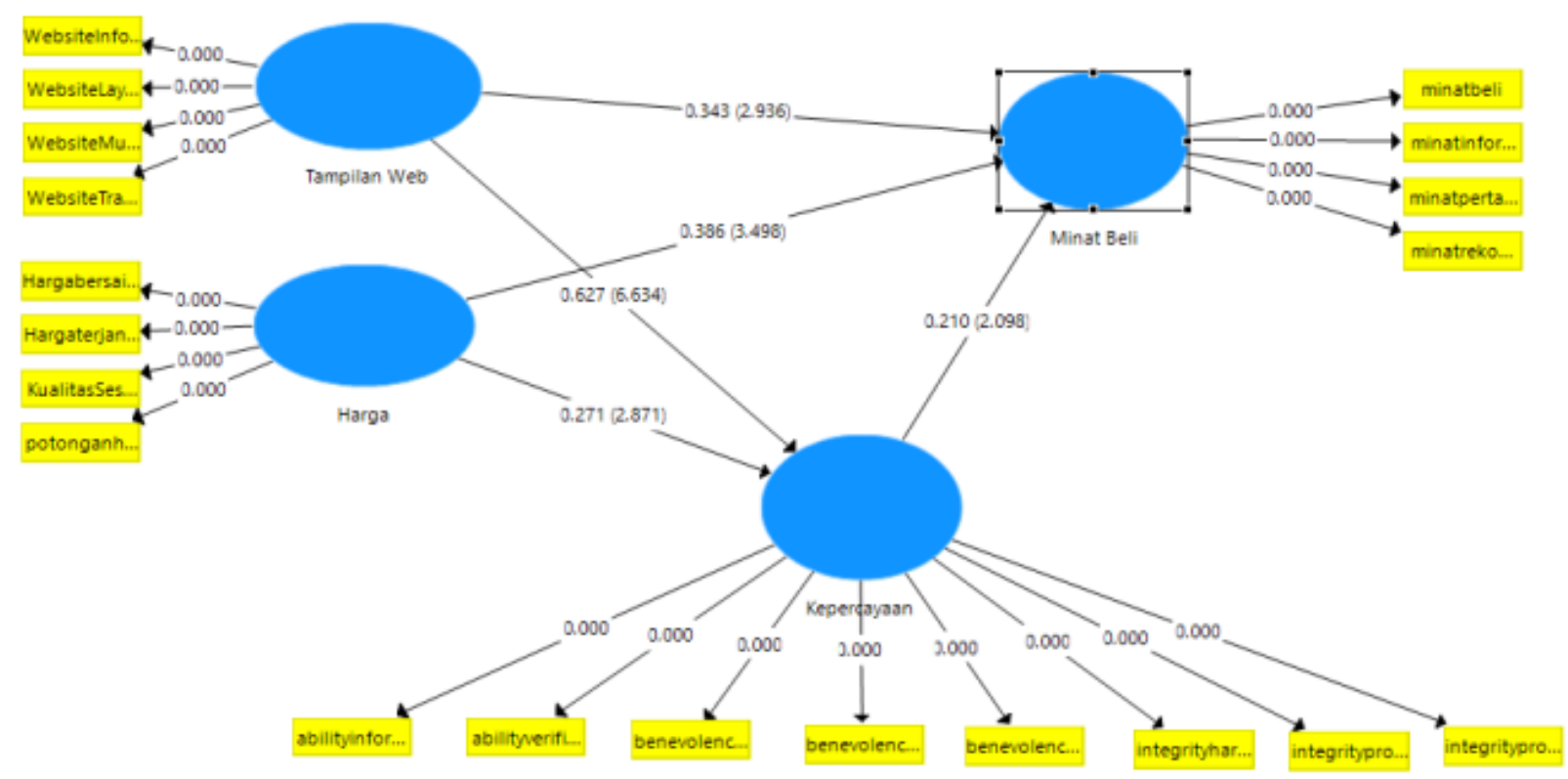

Gambar 2. Hasil Path Analysis 
Hubungan tampilan web terhadap minat beli secara langsung menunjukan angka 0,343 dimana angka yang menunjukan hubungan positif secara langsung. Hubungan harga terhadap minat beli juga secara langsung menunjukan angka 0,386 dimana angka yang menunjukan hubungan secara langsung yang positif.

Gambar 2 merupakan bukti bahwa dalam penelitian ini kepercayaan mengintervening hubungan antara variable independen terhadap variable dependen, sehingga dapat dikatakan kepercayaan juga merupakan variabel kuasi yang bisa menjadi variabel perantara yang independen.

Selain itu, keseluruhan variable dalam model ini memiliki path coefficient dengan angka yang positif. Sehingga jika semakin besar nilai path coefficient pada satu variable independen terhadap variable dependen tersebut, maka semakin kuat juga pengaruh antara variable independen terhadap variable dependen tersebut.

\section{Cross Loading Factor}

Pada tabel dibawah ini validitas cross loading factor sudah memenuhi syarat sehingga sudah dapat menggambarkan indikator dari variabel. Cross loading dari masing-masing indikator utama terlihat lebih besar dari indikator variabel lainnya. Dengan hasil data diatas menggambarkan bahwa indikator dari seluruh variable sudah dapat menggambarkan variabel tersebut dibandingkan dengan variabel lainnya.

Tabel 1. Cross Loading

\begin{tabular}{|c|c|c|c|c|}
\hline & (Z1) & (Y1) & (X2) & (X1) \\
\hline $\mathrm{X} 1.1$ & 0.762 & 0.708 & 0.682 & 0.850 \\
\hline X1.2 & 0.622 & 0.616 & 0.652 & 0.760 \\
\hline X1.3 & 0.701 & 0.693 & 0.667 & 0.825 \\
\hline X1.4 & 0.580 & 0.621 & 0.579 & 0.713 \\
\hline X2.1 & 0.660 & 0.700 & 0.874 & 0.730 \\
\hline $\mathrm{X} 2.2$ & 0.685 & 0.718 & 0.827 & 0.710 \\
\hline X2.3 & 0.607 & 0.697 & 0.810 & 0.622 \\
\hline X2.4 & 0.665 & 0.662 & 0.827 & 0.667 \\
\hline Y1.1 & 0.712 & 0.798 & 0.677 & 0.705 \\
\hline Y1.2 & 0.696 & 0.859 & 0.688 & 0.724 \\
\hline Y1.3 & 0.626 & 0.832 & 0.702 & 0.676 \\
\hline Y1.4 & 0.597 & 0.787 & 0.658 & 0.636 \\
\hline Z1.1 & 0.818 & 0.687 & 0.707 & 0.744 \\
\hline $\mathrm{Z} 1.2$ & 0.843 & 0.653 & 0.650 & 0.728 \\
\hline Z1.3 & 0.841 & 0.669 & 0.682 & 0.689 \\
\hline Z1.4 & 0.843 & 0.714 & 0.651 & 0.752 \\
\hline Z1.5 & 0.798 & 0.703 & 0.625 & 0.686 \\
\hline Z1.6 & 0.850 & 0.625 & 0.637 & 0.653 \\
\hline Z1.7 & 0.831 & 0.649 & 0.632 & 0.716 \\
\hline Z1.8 & 0.840 & 0.652 & 0.637 & 0.682 \\
\hline
\end{tabular}

\section{Uji Hipotesis}

Tabel 2. Kesimpulan Hipotesis

\begin{tabular}{|c|c|c|c|}
\hline & Jalur & P Values & Keterangan \\
\hline H1 & $\begin{array}{l}\text { Harga }(X 2) \rightarrow \text { Minat Beli } \\
(Y 1)\end{array}$ & 0.000 & Signifikan \\
\hline $\mathrm{H} 2$ & $\begin{array}{l}\text { Tampilan Web (X1) } \rightarrow \\
\text { Minat Beli (Y1) }\end{array}$ & 0.002 & Signifikan \\
\hline H3 & $\begin{array}{l}\text { Harga }(X 2) \rightarrow \\
\text { Kepercayaan }(Z 1)\end{array}$ & 0.006 & Signifikan \\
\hline $\mathrm{H} 4$ & $\begin{array}{l}\text { Tampilan Web }(\mathrm{X} 1 \rightarrow \\
\text { Kepercayaan }(\mathrm{Z} 1)\end{array}$ & 0.000 & Signifikan \\
\hline H5 & $\begin{array}{l}\text { Kepercayaan }(\mathrm{Z} 1) \rightarrow \\
\text { Minat Beli (Y1) }\end{array}$ & 0.018 & Signifikan \\
\hline
\end{tabular}

a. Temuan: terima H1.

Harga PT. Shopee Indonesia berpengaruh secara signifikan terhadap minat beliyang dapat dilihat pada table secara signifikan dengan nilai uji $T$ statistic 3.601>1.96 dan P-values >0.05.

Penelitian ini mempunyai hasil yang menunjukan bahwa harga berpengaruh signifikan terhadap minat beli yang dimana hal ini sesuai dengan pendapat (Prabowo, 2016) bahwa harga sangat mempengaruhi minat beli dikarenakan kemampuan konsumen untuk membeli sebuah produk ditentukan dengan uang yang mereka miliki dan membandingkan dengan fasilitas yang mereka dapatkan ketika membeli suatu produk. Harga merupakan salah satu penentu pemilihan produk yang nantinya akan berpengaruh terhadap minat pembelian (Bachriansyah \& Rizky, 2011).

b. Temuan: terima $\mathbf{H 2}$.

Tampilan web PT. Shopee Indonesia berpengaruh secara signifikan terhadap minat beli yang dapat dilihat pada table secara signifikan dengan nilai uji $T$-statistic 3.170>1.96 dan P-values >0.05.

Penelitian ini mempunyai hasil yang menunjukan bahwa tampilan web berpengaruh signifikan terhadap minat beli yang dimana hal ini sesuai dengan pendapat (Chen \& Dhillon, 2003) bahwa dalam kasus belanja online, situs web adalah satusatunya cara perusahaan berkomunikasi dengan pelanggannya. Oleh karena itu, tampilan dan strukturnya dapat mendorong atau mengecilkan minat pembelian konsumen. Situs jual beli online dapat dikatakan baik bila situs tersebut menyediakan petunjuk jelas alur bertransaksi, mulai dari pemesanan, pembayaran, pengisian form, hingga produk sampai di tangan pembeli. Situs jual beli online tidak hanya harus menarik secara teknis, tetapi juga harus mudah dalam penggunaannya agar memberikan dorongan terhadap penggunanya untuk memiliki minat beli di situs tersebut. 
c. Temuan: terima $\mathbf{H 3}$.

Harga produk PT. Shopee Indonesia berpengaruh secara signifikan terhadap kepercayaan yang dapat dilihat pada table secara signifikan dengan nilai uji T-statistic 2.737> 1.96 dan P-values $>0.05$.

Penelitian ini mempunyai hasil yang menunjukan bahwa harga berpengaruh signifikan terhadap kepercayaan yang dimana hal ini sesuai dengan pendapat (Cahyaningdyah, 2013) bahwa dalam transaksi online, konsumen mau membayar harga lebih tinggi bagi vendor yang lebih bisa dipercaya. Shopee dalam membangun kepercayaan telah memberikan harga yang transparan dan sesuai dengan kualitasnya, agar pengguna aplikasi Shopee memiliki tingkat kepercayaan yang tinggi dalam menggunakan Shopee.

d. Temuan: terima H4.

Tampilan web PT. Shopee Indonesia berpengaruh secara signifikan terhadap kepercayaan yang dapat dilihat pada table secara signifikan dengan nilai uji T-statistic $6.690>1.96$ dan P-values $>0.05$.

Penelitian ini mempunyai hasil yang menunjukan bahwa tampilan web berpengaruh signifikan terhadap kepercayaan yang dimana hal ini sesuai dengan pendapat (Zhang, Zhu, \& Huang, 2009) bahwa tampilan sebuah web dapat meningkatkan kepercayaan konsumen yang melakukan transaksi secara online, karena konsumen yang bertransaksi secara online mengandalkan informasi yang di dapat dari website yang menjual produk dan jasa tersebut. (McKnight, Choudhury, \& Kacmar, 2002) menyatakan bahwa faktor-faktor yang mempengaruhi kepercayaan pelanggan terhadap sebuah situs web menjadi tiga kategori, salah satunya adalah tampilan web yang memadai. Kepercayaan konsumen untuk vendor berbasis internet dapat terletak pada karakteristik individu dari konsumen, vendor Internet, situs web dan interaksi konsumen dengan vendor Internet melalui situs web. (Chen \& Dhillon, 2003)

e. Temuan: terima $\mathbf{H 5}$.

Kepercayaan PT. Shopee Indonesia berpengaruh secara signifikan terhadap minat beli yang dapat dilihat pada tabel secara signifikan dengan nilai uji $T$-statistic 2.363>1.96 dan P-values $>0.05$.

Penelitian ini mempunyai hasil yang menunjukan bahwa harga berpengaruh signifikan terhadap minat beli yang dimana hal ini sesuai dengan pendapat (Ricky \& Adrian, 2012) bahwa faktor kepercayaan memiliki pengaruh langsung pada minat beli konsumen. Dalam konteks berbelanja online, hubungan antara keduanya bersifat positif berlaku terhadap pembeli potensial. Hanya pelanggan yang memiliki kepercayaan yang akan berminat untuk membeli secara online. Kurangnya kepercayaan mencegah pembeli dari terlibat dalam belanja online (Endi \& Lilis, 2014).

\section{KESIMPULAN}

Seluruh variable dalam penelitian ini menunjukkan suatu pengaruh, namun berdasarkan path coefficient menunjukan bahwa dalam penelitian ini kepercayaan memperlemah hubungan antara variable independen yang merupakan tampilan web dan harga terhadap variable dependen yang merupakan minat beli, melainkan hubungan secara langsung antara variable independen ke variable dependen lebih kuat.

\section{SARAN}

PT. Shopee Indonesia telah memiliki sistem yang baik dalam membangun kepercayaan dan minat beli. Namun, terkadang PT. Shopee Indonesia kurang memperhatikan hal berikut ini:

- Kelengkapan informasi yang tertera pada website dan aplikasi Shopee

Penulis memberikan saran pada pihak Shopee agar lebih meningkatkan informasi website yang diperlukan konsumen untuk melakukan untuk lebih meningkatkan kepercayaan serta minat beli yang dimiliki oleh konsumen. Caranya adalah dengan menyediakan template/format upload produk dengan keterangan yang mendetail, seperti: nama produk, jenis produk, bahan/material, pilihan warna, pilihan ukuran, serta kota asal pengiriman; tidak seperti saat ini yang hanya mengandalkan caption/keterangan bebas dari pihak penjual.

- Peningkatan strategi keterjangkauan harga Penulis memberikan saran pada pihak Shopee agar lebih meningkatkan strategi harga misalnya mengadakan event membeli bersama akun lain akan memperoleh potongan harga atau adanya layout yang memiliki tombol share ke platform komunikasi.

\section{DAFTAR PUSTAKA}

Adidarma, R. A. dan W. (2016). Pengaruh Kepercayaan Dan Risiko Pada Minat Beli Belanja Online. Jurnal Manajemen Dan Bisnis Sriwijaya, 14, 1-14.

Bachriansyah, \& Rizky, A. (2011). Analisis Pengaruh Kualitas Produk, Daya Tarik Iklan, dan Persepsi Harga terhadap Minat Beli Konsumen pada Produk Ponsel Nokia, hal. 1-65.

Bilondatu, M. R. (2013). Motivasi, Persepsi, Dan Kepercayaan Pengaruhnya Terhadap Keputusan Pembelian Konsumen Pada Sepeda Motor Yamaha Di Minahasa. Emba Issn 2303-1174, 1(3), 710-720. 
Cahyaningdyah, D. (2013). Jurnal Dinamika Manajemen. Jurnal Dinamika Manajemen Http://Journal.Unnes.Ac.Id/Njw/Index.Php/Jdm ANALISIS, 4(2), 184-191. https://doi.org/10.1017/CBO97 81107415324.004

Chen, S. C., \& Dhillon, G. S. (2003). Interpreting Dimensions of Consumer Trust in E-commerce. Information Technology and Management, 4, 303-318. https://doi.org/10.1023/a:102296263 1249

Churchill, G. A. (2005). Dasar-dasar riset pemasaran Jilid 1 Ed.4. Jakarta: Erlangga.

Das, T. K., \& Ten, B.-S. (1998). Between Trust and Control: Developing Confidence in Partner Cooperation in Alliances Author (s): T. K . Das and Bing-Sheng Teng Source: The Academy of Management Review, Vol. 23, No. 3 (July, 1998), pp . 491-512 Published by: Academy of Manag. The Academy of Management Review, 23(3), 491-512.

Endi, R., \& Lilis, H. (2014). Beberapa faktor yang berpengaruh terhadap minat beli online pada situs jual beli tokobagus.com. Jurnal Fakultas Ekonomi Dan Bisnis Universitas Mercu Buana, 2(3), 311-318.

Ferdinand, A. (2002). Pengembangan Minat Beli Merek Ekstensi.

Gregg, D. G., \& Walczak, S. (2010). The relationship between website quality, trust and price premiums at online auctions. Electronic Commerce Research, 10(1), 1-25. https://doi.org/10.1007/ s10660-010-9044-2

Hahn, K. H., \& Kim, J. (2009). The effect of offline brand trust and perceived internet confidence on online shopping intention in the integrated multi-channel context. International Journal of Retail and Distribution Management, 37(2), 126-141. https://doi.org/10.1108/09590550910 934272

Howard, J. A. (1994). Consumer Behavior in Marketing Strategy.

Jarvenpaa, S. L., Tractinsky, N., \& Vitale, M. (2000). Consumer Trust in an Internet store. Journal of Information Technology Management, 1, 4571. https://doi.org/10.1111/j.1083-6101...Back

Kinnear, T. C., \& Taylor., J. R. (1996). Marketing Research: An Applied Approach. USA: McGrawhill.

Kotler, P. (2005). Manajemen Pemasaran (11th ed.). Jakarta: Indeks.

Kotler, P., \& Armstrong, G. (2008). Prinsip-prinsip Pemasaran.

Kotler, P., Bowen, J., \& Maken, J. (1999). Marketing for Hospitality and Tourism. Pretince Hall.

Koufaris, M., \& Hampton-Sosa, W. (2004). The development of initial trust in an online com- pany by new customers. Information and Management, 41(3), 377-397. https://doi.org/ 10.1016/j.im.2003.08.004

Kurnia, D. (2010). Pengaruh Iklan dan Word Of Mouth (WOM) Terhadap Minat Beli Mahasiswa Universitas Negeri Padang Atas kartu Perdana IM3. Fakultas Ekonomi Universitas Negeri Padang, (1), 1-9.

Lohse, G. L., \& Spiller, P. (1998). Electronic shopping. Communications of the ACM, 41(7), 81-87. https://doi.org/10.1145/278476.278491

Mayer, R. C., Davis, J. H., \& Schoorman, D. F. (1995). An Integrative Model of Organizational Trust Author (s): Roger C. Mayer, James H. Davis and F. David Schoorman Source: The Academy of Management Review, Vol. 20, No. 3 (July, 1995), pp. 709-734 Published by: Academy of Management Stable UR. Academy of Management Review, 20(3), 709-734.

McKnight, D. H., Choudhury, V., \& Kacmar, C. (2002). Developing and validating trust measures for e-commerce: An integrative typology. Information Systems Research, 13(3), 334-359. https://doi.org/10.1287/isre.13.3.334.81

Njite, D., \& Parsa, H. G. (2005). Structural equation modeling of factors that influence consumer internet purchase intentions of services. Journal of Service Research, 5(1), 43-59.

Parasuraman, A. (1991). Marketing research $2^{\text {nd }} e d$. Reading, Massachusetts: Addison-Wesley Publishing Company.

Pavlou, P. A., \& Dimoka, A. (2006). The nature and role of feedback text comments in online marketplaces: Implications for trust building, price premiums and seller differentiation. Information Systems Research, 17(4), 392-414. https://doi.org/10.1287/isre.1060.0106

Penitasari, N. (2017). Pengaruh Harga dan Kualitas Produk Terhadap Minat Beli Abon Lele. Management Marketing, 10-24. https://doi.org/23017775

Prabowo, I. J. K. G. (2016). Pengaruh citra merek, kualitas produk, persepsi harga dan word of mouth terhadap minat beli (Studi pada Mahasiswa Fakultas Ekonomi UNY Pengguna iPhone), 246-256.

Prasetyo, S., \& Widodo, T. (2017). Anteseden Kepercayaan Pengguna Pada Penawaran E-Commerce Dan Konsekuensinya Terhadap Niat Beli (Studi Pengguna E- Commerce Provinsi Dki Jakarta) Antecedent of Trust Users on Offering E-Commerce and Its Consequences To the Purchase Intention (Study User, 4(2), 14291436. 
Ricky, S., \& Adrian, A. (2012). Effects of Perceived Trust and Perceived Price on Customers' Intention to Buy in Online Store in Indonesia. Asean Marketing Journal, 4(1), 26-36. Retrieved from http://journal.ui.ac.id/index.php/amj/ article/view/2029

Rosandiena, T. T., \& Indrojarwo, T. B. (2018). Perancangan Website sebagai Media Penjualan Online IKM di Jawa Timur, 7(1).

Schurr, P. H., \& Ozanne, J. L. (1985). Bargaining Toughness Linked references are available on JSTOR for this article: Influences on Exchange Processes: Buyers 'Preconceptions of a Seller' $s$ Trustworthiness and Bargaining Toughness, 11(4), 939-953.

Siagian, H., \& Cahyono, E. (2014). Analisis Website Quality, Trust Dan Loyalty Pelanggan Online Shop. Jurnal Manajemen Pemasaran, 8(2), 5561. https://doi.org/10.9744/pemasaran.8.2.55-61

Sulistyari, ikanita noviriana. (2012). Analisis Pengaruh Citra Merek, Kualitas Produk, Dan Harga Terhadap Minat Beli Produk Oriflame, (analisis pengaruh citra merek, kualitas produk, dan harga terhadap minat beli produk oriflame), 72 .
Tambunan, K. (2012). Analisis Pengaruh Citra Merek, Persepsi Kualitas, dan Persepsi Harga Terhadap Keputusan Pembelian Bandeng Presto, 1(8), 1-21.

Wahdi, M. (2011). Riset pemasaran: teori dan aplikasi untuk pengambilan keputusan cet. 1 . Jakarta: Caps (Center for Academic Publishing Service).

Wicaksono, B. L., Susanto, A., \& Winarno, W. W. (2012). Evaluasi Kualitas Layanan Website Pusdiklat BPK RI Menggunakan Metode WebQual Modifikasi Dan Importance Performance Analysis. Media Ekonomi \& Teknologi Informasi, 19(1), 21-34.

Yusnidar, Samsir, \& Restuti, S. (2014). Pengaruh Kepercayaan dan Persepsi Resiko Terhadap Minat Beli dan Keputusan Pembelian Produk Fashion Secara Online di Kota Pekanbaru. Jurnal Sosial Ekonomi Pembangunan, IV(12), 311-329.

Zhang, L., Zhu, M., \& Huang, W. (2009). A framework for an ontology-based e-commerce product information retrieval system. Journal of Computers, 4(6), 436-443. https://doi.org/ 10.4304/jcp.4.6.436-443. 